\title{
CELINA MARÍA MATTERI \\ (1943-2004)
}

El 30 de noviembre de 2004, a los 61 años, en la provincia de Buenos Aires, falleció la Prof. Celina María Matteri, después de una penosa enfermedad, que no le impidió redactar sus últimos trabajos, corregir los que teníamos en marcha y por que no decirlo, programar las actividades futuras.

Celina dedicó su vida al estudio de los musgos. Su interés por este grupo de plantas había comenzado en la década del 60, bajo la dirección de la Dra. Gabriela H. de Menéndez, en el Museo Argentino de Ciencias Naturales Bernardino Rivadavia, el que con el paso de los años se convirtiera en su segunda casa.

La pasión y entusiasmo que ponía frente a estos organismos

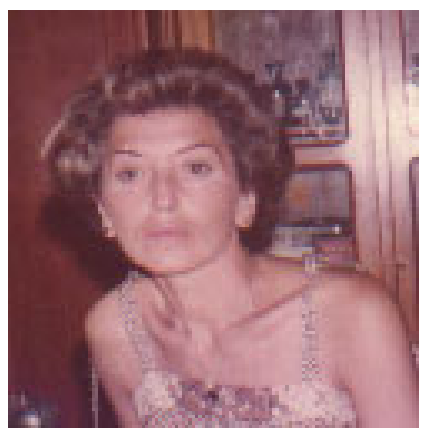
hizo que los conociera tanto por haber visitado los herbarios más importantes del mundo y haberse perfeccionado al lado de destacados investigadores, como por estudiarlos en su hábitat natural.

Fue una incansable coleccionista, recorrió distintos países y casi toda Argentina coleccionando y observando los musgos de las distintas regiones geográficas, aunque fue la región Andino Patagónica a la dedicó sus mayores esfuerzos. Tuve el privilegio, como todos los que nos interesamos en el estudio de los musgos, de compartir extensas y agotadoras campañas. Cuando intuía que las fuerzas se nos estaban agotando, revivía su espíritu alegre y divertido, que con una frase o un comentario oportuno nos cambiaba el humor.

$\mathrm{Su}$ vasta trayectoria científica ha quedado impresa en más de 100 trabajos en revistas nacionales e internacionales de reconocida trayectoria así como en capítulos de libros.

Quienes pasamos por su laboratorio, no podemos dejar de valorar su espíritu generoso para escuchar, sentarse frente al microscopio con nuestros problemas y apelar a su memoria prodigiosa para extraer de su biblioteca personal lo que necesitábamos. Hoy por decisión de su familia esa biblioteca, de un valor incalculable, sigue con vida en nuestro laboratorio de la Fundación Miguel Lillo.

Su espíritu participativo la llevó a tomar parte activa de la Sociedad Argentina de Botánica, fue socia fundadora de la Sociedad Latinoamericana de Briología y Presidente ejecutivo del VI Congreso Latinoamericano de Botánica.

A casi un año de su fallecimiento vayan estas líneas como un sentido homenaje a quien fuera mi amiga, colega y maestra por casi tres décadas.

María Magdalena Schiavone 